\title{
Reflections of Social Darwinism on Physical Education and Sports in the Early Turkish Republican Period
}

\author{
Sevda Korkmaz (Corresponding author) \\ Istanbul Major Municipality, İstanbul, Turkey \\ E-mail:svdkrkmz0@gmail.com
}

Received: September 30, 2020 Accepted: November 1, 2020

Published: November 17, 2020

doi:10.5296/jei.v6i2.17765 URL: https://doi.org/10.5296/jei.v6i2.17765

\begin{abstract}
In the 19th century, with the spread of nationalism movement, the power and capital on which the state was based changed, and man replaced the land. Mechanization and industrialization accelerated imperialism, and the application of the emphasis on competition in nature to social spheres in the theory of evolution became a means to legitimize capitalist competition and the paths applied. In order to stand out in the competitive environment, both the durable workforce for economic progress and the military power to defend the imperial competition gains were of great importance. While this situation increased the value of human life and therefore their bodies, it also gave rise to the idea that strong bodies are the basis of strong states and caused it to become widespread in a short time. The number of recreational areas such as parks and gardens and sports facilities that would increase the life capacity and quality of people increased, physical education and sports were included in the education curriculum of military and civilian schools, scouting and gymnastics formations were supported and all these developments spread rapidly in Europe. The Ottoman Empire also considered physical education and sports as a way to get rid of destruction, and the Republic of Turkey, established in its place, gave a special importance to physical education and sports as a means of preserving and maintaining its existence as a means of building robust generations.
\end{abstract}

Keywords: Social Darwinism, Physical education, Sports, Early Turkish republican period

\section{Introduction}

\subsection{Introduce the Problem}

In the first half of the 19th century, when a direct relationship was observed between public health and the health of the state (Şişman, 2006), human life and health constituted the main 
agenda of politics (Foucault, 2011). The body, which Foucault defined as 'the recording place for events' (Foucault, 2004), became the subject of social movements for sanitary reform, with disease prevention becoming a political and economic science at the end of the 19th century. New models were developed to protect the health of the population, and the number of socio-medical research increased rapidly. For politicians, the strategies of building a healthy society were more important than ever before (Porter, 2005). In this sense, social Darwinism, based on the adaptation of the theory of evolution developed by Darwin to social sciences, has been an important reference source. In the struggle for survival with social Darwinism, which can be summarized as "life is a struggle, natural selection takes place, the best survive", the idea that "natural selection/adaptation to the environment" will occur, and in order to be successful here and ensure the survival of the nation, the idea of being ready for a total war and entering it when necessary started to prevail. In this sense, since the best will survive and ensure the continuation of their generations, the understanding of waging a total war in the form of an existence-extinction and displaying all 'abilities' of the nation emerged (Yücel \& Taşar, 2016). Physical education and sports at the point of displaying talent, or power in other words, found a privileged place in the policies of the states in a short time because they were a very direct and economic tool in the monarch point of raising strong soldiers to fight when necessary, durable workers to work in factories and robust generations. Gymnastics institutions with these aims were born in a short time in the field of physical education and sports and spread throughout Europe in a short time. This situation showed its effects both in the Ottoman Empire and the Republic of Turkey just like in Europa. In this study, in the context of social Darwinism, the perspective on physical education and sports in the early republican period, expectations from this field, and the programs and policies implemented were examined using the literature review method.

\section{Method}

In this article, the findings obtained by the literature review (Demirci, 2014; Keser, n.d.) method, which makes it possible to examine, compile, classify and synthesize a large number of studies due to the research subject, have been evaluated. The sources obtained through the literature review (Balc1, 2006), which helped the research to be based on a historical perspective by using the library and archives, were examined and the research findings were evaluated from a historical-sociological perspective.

\section{Results and Discussion}

With the establishment processes of nation-states accelerated by the nationalism movement, capitalism and imperialism, which gained speed after industrialization, turned the 19th century into an age of competition, and the concept of competition in nature of the theory of evolution gained legitimacy by adapting it to capitalist competition. In this period when the struggle for supremacy was undertaken, the way to win the struggle was to ensure the multiplicity and health of the population.

Under the tensions and pressures of an insecure world in which nation-states, whose population decreased during the war and then under the threat of another war, tried to exist by competing with each other, it found more room to spread. The idea that health concerns 
society, the country needs a racially healthy generation, and therefore the state has to show people how to live by interfering with their private lives spread rapidly (Mazower, 2010). Gymnastics emerged as a performance universe that put forward decisive measures and efficiency principles and whose results can be calculated. In a short time, gymnastics was used in hospitals to correct bodily irregularities, in factories to increase production efficiency, and in schools and the army to make the discipline effective (Holt \& Vigarello, 2011). Physical fitness was encouraged by cycling on extended holidays after World War I, swimming in newly built public pools, and hiking in the countryside (Mazower, 2010).

Exercises performed in a certain order with calculated intervals not only make the young members of the society adopt the rules of "civilized behavior" such as "listening habits", but also create a new life culture in these people. This art of movement became an indispensable form of the nation states' efforts to present themselves on bodily signs as we were entering the last quarter of the 19th century (Holt \& Vigarello, 2011). In a short time, physical education and sports practices became components of educational curricula. Sports associations and clubs started to be supported by the states. With this movement art, a "social vitality" was created in order to reach the "dreamed/desired society".

Because bodies not only move but are also built in physical education (Webb et al, 2008) on the one hand, physical education became an essential component of practices aimed at enhancing the health of the population, on the other hand, its militaristic aspect gradually increased as a result of the needs in the military field. The issue of empowering nation members physically and preparing them for possible wars was tried to be resolved through paramilitary gymnastic institutions (like German Jahn gymnastics and Czech Sokol organization) based on physical education and mostly acting with nationalist motives. Gymnastics was considered as a tool of national power and unity, and it was aimed to strengthen the children of the country in order to win wars, as well as to gain traits such as obedience and discipline. Again, physical education conducted together was used for the mass to reach national awareness and to realize that everybody was part of a whole (Yamak, 2012). Gymnastics performances became a tradition at events celebrating national days, and pace all together expressed an excitement referring to the love of homeland (Holt \& Vigarello, 2011). With the marches sung in mass gymnastic shows (Steinitzer, 1912), the feeling of homeland was wanted to be reinforced. The squares, which were one of the venues where politics turn crowds into coherent political forces, also became places for mass events such as sports. New symbols and myths were used in these squares to serve new purposes (Mosse, 1975). These developments in Europe affected the Ottoman Empire and the Republic of Turkey established after it, as well as many other countries, and physical education was used in modernization studies.

\subsection{Social Darwinism in the Ottomans}

With the modernization efforts, which gained a concrete appearance and application area in the Ottoman Empire from the second half of the 19th century, not only technical knowledge entered the country, but also the understanding and thought movements in the west. Social Darwinist thought found a wide spreading area among Ottoman intellectuals, especially 
through the experts from Germany, who were in cooperation due to the political conditions of the period. However, the perception that strong states will survive and the weak will be erased from the stage of history (Tanar, 2011) enabled the opening of health and hygiene institutions, physical education lessons in the school curriculum, and writing books and articles.

When the daily newspapers, magazines and tracts of the Ottoman Sultan Abdulhamid period were examined, topics such as modern baby care methods, healthy child breastfeeding and general hygiene rules were among the popular themes frequently discussed. The Ottoman elite and especially the medical professionals made great contributions to the formation of a public discourse on public health and hygiene (Özbek, 2013). The same way was observed in the Ottoman Empire, as in Europe, with a view to the relationship between health and physical education and sports and the militarist emphasis. It is possible to see the propaganda works made to spread this discourse in period publications.

Among these, Aka Gündüz (Enis Avni), one of the important writers of both the Second Constitutional Era and the first years of the Republic, and a member of the National Defense Association, stated in his article that he would raise his son Doğan in accordance with the "struggle for life". Another example is the two articles titled "Weak Race" by Burhaneddin [Felek] Bey, the president of the Anatolian Sports Club and also one of the important sportsmen of the Republic Period. Burhaneddin Bey claimed in his article that there was no better example of the weak race than the Ottomans. According to the author, there were two ways to avoid being the weak race: first, avoiding entertainment, not drinking and smoking, and second, physical education. Behind the views of Burhaneddin Bey, regarding healthy living, there was an imagination of a nation consisting of strong individuals. Burhaneddin Bey, who asked the question of "Does physical education strengthen the race?", answered his question as follows: "... If the nation consists of solid men, it can work, otherwise it cannot. When it is not able to work, the service expected by the country cannot be performed and progress cannot be achieved. ... Delegations of rotten individuals become rotten, and if they are rotten, they cannot work as well. Then it leaves its place to the one who works. This is a danger. Its origin is also the weak race. Therefore, I consider this weakness a national danger." (Cora, 2013).

The shocking effect of the results of the Balkan Wars on bureaucrats and intellectuals of the period played a major role in the prominence of eugenic approaches. Defeat was not only seen as a military failure, but as a social weakness resulting from the bodily inadequacy of the Ottomans: "We say living is a fight. The reign is in the strength in the fight. The strong pushes the weak and drives it. The weak lives desperately; it is always a slave to the strong ... This terrible scourge that crushed and battered the nation so much, burned the country and burned the state is the weakness of the Turkish. My nation fell, but it also fell from power!" (Beşikçi, 2009). As a way of eliminating this weakness, realizing physical education activities and spreading the application areas of these activities were the primary fields of activity of the elites of the period.

The established associations also operated with a program content that would serve the same 
purpose. Toprak (1979), in his article named 'Paramilitary Youth Organizations of the Committee of Union and Progress', while establishing the Scouting organization of the Turkish Power Association, he included the following lines, which convey the connection between the German Scout organization and the German nation, in a document considered as the declaration of the association: "At the time of Napoleon's invasion of Prussia, the most important of Prussia's national defense attempts was to establish gymnastic societies (Note 1). Yahn, which the Prussians today call "man of the body," shocked and awakened the Prussian youth. It activated the blood in their veins. On the one hand, Yahn was training young people with gymnastics, on the other hand, the poet named Mortiz Arndt encouraged the uprising of the young galahads as follows: 'The god who created iron did not want slavery; for this, he gave a sword, shield and spear into the man's hand. He presented the courage of bravery to his heart and the rage and violence of free speech to his tongue; so that human beings may fight with their blood and life until they die. Their gymnasium were rural areas and forests. Yahn would gather volunteers, take long walks, show them around their country, teach. In a short time, they did not leave a place where I did not set foot. There was no trace, no passage left. So much so that at a time when the country was full of French soldiers, these young defenders were rushing from continent to continent, bringing news without appearing to the enemy. Germans called them Pfadfinder (trail finder)". These lines emphasize the importance of gymnastics by emphasizing that the most important initiative for the defense of the homeland for the Germans is to establish gymnastic societies, thus young people take action, and also mentions the importance of scouts to know their homeland. In addition, the same results are indicative of the desire to create a public opinion regarding the necessity of physical education and scouting activities for Turks as a concrete example for Germany as a model.

In his study, Toprak (1979) underlines that the main concern of the association in question was "to save Turkishness from destruction and denial, and to create a strong and crowded generation of deeds like our future ancestors, a generation of Turks who rely only on their own strength in order to protect their homeland, law, honor and discovery". It was specifically stated in the regulation that a Physical Education branch was opened by taking the guiding organization in Europe as a model in order to raise strong young people for the army within the association (Taşkesenlioğlu, 2009).

The understanding that aims to turn the whole nation into an "armed nation (army-nation)" by saying, "Behind a strong army, there is always a reserve army consisting of a strong youth" (Balcığlu, 1999), penetrated among the Ottoman elites through von der Goltz, who was appointed to the head of the German reform committee in the Ottoman country. Goltz (Note 2) (Ünder, 2001) Pasha, who was the head of the German military delegation and regarded as the most influential person in the regulation of the Ottoman military system, was instrumental in the inclusion of military drills and a militarist physical education understanding into the education curriculum, thanks to the officer students who he trained in line with this understanding and took important positions in the country's administration.

As can be seen, the historical conditions and the environment created by the wars one after the other, the understanding of "total preparation for war", patriot love and belief in theory, 
and physical education practices equipped with the aim of strengthening the body in practice were developed. In addition, the necessity of making regulations in many areas, especially public health, emerged, and public opinion was created in this direction.

The Republic of Turkey, which was established after the Ottoman Empire, needed strong and healthy individuals both to keep the new generations ready for a possible war and to ensure development that would reach the level of modern civilizations, and it acted by putting this at the center of almost all its policies. When we examine the press of the period, it is seen that physical education and sports are also handled in the same direction.

\subsection{Republic of Turkey}

Riza Tevfik and Selim Sirr, two important names of the period, thought about movement and body and wrote articles stating that 'strength' was as important as the health of the body, with an interest in developing the human body. Furthermore, the two names stand out that they established a direct relationship between folk dances and the national state for the first time (Öztürkmen, 2002). Especially Tarcan's zeybek received special praise from Atatürk. They had a distinct meaning and importance in terms of fulfilling an important first in the process of creating a nation state.

During the difficult and painful process of transforming from a cosmopolitan empire to a nation-state, the main problem of the founding staff of the Republic was to replace the old values that held society together, but not to lose the national identity while moving to a new order (Bora, 2012). Akın (2014) summarizes this situation as follows: From the middle of the 19th century, the problems within the scope of biopolitics began to be on the agenda of those who ruled the Ottoman Empire. In order to solve these problems, policies were tried to be produced in empire scale. It is not surprising to see that the same concerns were also on the agenda of the republican elites after the proclamation of the republic. The problems faced by a population that was devastated for various reasons and the destructed manpower constituted the most vital agenda item of the early Republic governments.

The founders of the Republic also undertook the mission of creating a "Strong Turk" with their reaction to the image of the old and weak Turkish stigmatized as "sick man". The Republic, in the words of Mustafa Kemal, was in need of "robust and mean children". Strong bodies would be the foundation of the mighty republic. Bodies would also turn into an indicator that the Turkish people who established the Republic of Turkey were civilized/western. Policies carried out over bodies would be the means of the desired change and the way to restructure social and political life (Yumul, 2012). When one of the main goals of the founding ideology of the Republic was to raise healthy and strong generations that would ensure the continuity of the Republic of Turkey, physical education and sports were designed from the very beginning as a part and complement to cultural, scientific and practical education (Türkmen, 2012).

When the anxiety to increase the population, which manifested itself in the Constitutional period thought, combined with the concerns of the Republic elites in the thirties, it was also claimed that the population should be developed not only quantitatively but also qualitatively, 
a crowded and unhealthy population would not contribute to national economic development, and would harm social order and welfare (Alemdaroğlu, 2008). In addition to the sports practices in schools shaped by such concerns, how and to what extent sports will be included in the factories, the economic and health benefits of sports were tried to be conveyed to the society with the articles in the journals such as Ülkü, which is one of the publications of the community centers, in summary, every channel was tried to be used to achieve the goal of total "improvement".

In the May 1934 issue of Ülkü magazine, Fahrettin Kerim expresses this in his article titled 'The Nature of the Eugenique Issue in National Population Politics', in which he mentioned the importance of increasing the population in terms of quantity and quality, and the necessity of raising healthy individuals mentally and physically, since eugenics is a matter of state and national population politics: "The main objectives of each state's national population policy are to increase the population, reduce death, extend the life expectancy, and raise a healthy and fit population. When it comes to the health of the general public, no one can act alone ... Today, the individual is the most income capital of the state. Consequently, from the "Eugenique" point, we have to manage and protect this capital very well. The issue of national wealth and economics also govern this". In another article, it was emphasized that according to İsmet İnönü, first of all, the protection of life should be provided, and the race and the nation should have full potential to ensure this (Ink1lap Kürsüsünde, 1934).

Since eugenics was seen as a science, it legitimized the actions of states over the human body. In this respect, eugenics has an important place in programmed modern society design. Something that was scientifically correct could not be morally wrong, in line with the requirement that those who regard science as the source of absolute truth, all of the Kemalist elites, believed in the basic propositions of 19th century naive positivism, to evaluate racial correction policies as a scientific fact (Y1ld1z, 2001). Hence, the leaders among those who advocated the discourse were mostly medical professionals.

Not surprisingly, the first writing sample that stood out in the Republican era came from a doctor. This article is Dr. Fuad's translation from North American eugenist Margaret Sanger's book Family Limitation in 1927. In the introduction of the translation, Dr. Fuad emphasizes the importance of healthy and well-grown children in terms of social hygiene and the improvement of future generations, rather than many children (Alemdaroğlu, 2008). Based on the idea that healthy generations could only be raised by healthy mothers, women were also seen as objects of eugenic practices.

In a culture where the role of women is socially wife and mother, the use of sport as the most convenient tool in this sense is undoubtedly interesting, given that modernizing tools should not conflict with this function of women. The new woman of the Republic period should be equipped with a new conscience and morality and should be among the women of civilized nations with mental education and morality, not as Europeanized ornamental women, but as mothers with the awareness of the responsibility to raise children to the motherland. (Durakbaşa, as cited by Kavasoğlu \& Yıldıran, 2016). Women became symbols as the reflected face of modernization by taking part in the public sphere, and were considered as 
the breeders of the future generation in terms of both quantity and quality. Because, as required by the conditions of the period, women were given an important role in the aim of increasing the population, which suffered from wars one after another, in terms of quality as well as quantitatively.

Arpac1 states in his study that the population anxiety of the founding staff of the republic in this period developed on three grounds (Arpac1, 2015):

I. First of all, in the modernization process, there is a concern of creating a crowded population that will gradually gain a political meaning and fill the land with which a relationship of belonging is established.

II. Creating strong soldiers who will ensure the security of this land, population, and state constitutes another aspect of sensitivity towards bodies and population.

III. The desire to create healthy workers, that is, the labor force that will ensure economic development that will ensure the welfare of the population, constitutes the other line of the population anxiety that gradually increases in the process.

According to Arpac1 (2015), the population problematized through these lines is a phenomenon that needs to be known in every aspect, increased and strengthened, made healthy, educated and improved. This view, which sees as a condition of increasing the population and improving the bodies, realizing modernization, ensuring welfare and strengthening the state, equating the nation and the state with the power of the population in this context, aims to create a crowded, healthy and strong population as a "national cause" by consistently applying medical knowledge and practices. Population issue in the 1927 agenda of the party in power takes its place as follows: "Population policy will be the most important field of activity of our party." (Tuncay, 1999).

Again, in their papers presented to the First Turkish History Congress, Afet İnan, Fuat Köprülü and Şevket Aziz Kansu emphasized the beauty of the Turkish race (Y1ld1z, 2001). Physical education and sports activities, which are tools to reveal this beauty, were encouraged especially through the press. For this, even movie stars that stood out with their beauty were used. For example, Elizabeth Allen, one of the world stars of the period, was presented as follows: "Elizabeth Allen, one of the charming and attractive stars, is an athlete like all other artists. She likes all kinds of sports. She spends 15-20 minutes in the mornings with gymnastics and training movements like all her friends" (Elizabeth, 1934).

Participating in beauty contests in order to show the beauty of the Turkish nation to the world was also regarded as the changing face of Turkey and an indicator of the distance covered on the road to westernization. The first beauty contest, whose aim is to show the changing place of women in Turkey and the modernizing face of the country to the world, was organized by Cumhuriyet Newspaper (Note 3) in 1929. In the World Beauty Contest held in 1932, Keriman Halis was chosen as the world's beauty, and found a wide coverage in the country's press. The statement Mustafa Kemal Atatürk gave to the Chief Writer of the Republic due to the success is also very important in terms of reflecting the view of the period. The statement of M. Kemal is as follows: "... This beautiful Turkish girl is, of course, right to consider herself 
pleased and happy by introducing the beauty of her race to the world with the approval of world referees... Let me add that, since I know historically that the Turkish race is the most beautiful race in the world, I found it very natural that one of the Turkish girls was chosen as the world's most beautiful. However, I would like to remind the Turkish youth that: ... what you have to deal with is to hold world first in high culture and high virtue, as your mothers and ancestors were" (ATAM, 2006). As can be seen, the issue of public health, beautification and strengthening of the race were handled in a wide range for the founding cadres from the very top.

The theory of eugenics and social Darwinism had such an impact on the Kemalist elite that many books and articles were published, and scientific conferences were held to develop national racial improvement policies in order to have a healthy and high-quality Turkish population. The conferences of the CHP on the importance of race and inheritance and the translated articles published on the purity and strength of race in $\ddot{U} l k \ddot{u}$, the publication of the Ankara Community Center, are clear examples of the influence of race theory on the Kemalist elite (Yıldız, 2001).

In Ülkü magazine's article 'Turkey on the Population Issue' published in September 1939, Yaşar Nabi points out the importance of population issue both in times of war and peace: "The majority of the population is considered a means not only to have the largest armies in war, but also to secure the basis of the anticipated war in advance by creating a strong economic element in times of peace."

The importance given to the issue of eugenics and social Darwinism by the republican regime has found its clearest expression in Atatürk's words of "strong and robust generation is the yeast of Turkey" and in his speech on the tenth anniversary of the Republic, in his evaluation of protecting the nation from degrading dangers and creating a mentally and physically fit population density as one of the fundamental pillars of the Republic Revolution (Alemdaroğlu, 2008).

In the 1935 agenda of the party (C.H.P. Program1, 1935), it was stated that physical education should be used in order to ensure the health of the whole society, primarily the youth, and to raise individuals who would protect the country, and for this, the sports organization was designed in such a way that these principles would be implemented; "The Turkish youth will be attached to a national organization that will gather it in a clean morality, a love of homeland and revolution. All Turkish youth will be given physical education that will nourish their enthusiasm and health, and their beliefs in themselves and the nation, and the youth will be brought up with a mindset that recognizes the supreme duty of protecting the country with the revolution and all the conditions of maturity and keeps them ready to give all their assets for this duty. In order for this main training to bring results, on the one hand, the thinking, decision-making and entrepreneurial forces of the Turkish youth will be developed and on the other hand, the youth will employ it under the influence of strict discipline, which is the only element in achieving every difficult task. Sports organizations in Turkey will be organized and carried out according to these principles. Business and management unions, universities, schools and institutes, community centers, factories and institutions that use collective 
workers will be organized for the youth organization to be built, according to the above objectives. Uniformity in physical and revolutionary education and sports affairs at the dormitory will be taken into consideration. Those in schools, state institutions and private institutions and factories will be obliged to deal with physical education according to their age. Fields and institutions required for sports and physical education will be established."

It is possible to see the importance given by the republic to the issue of social Darwinism in the laws as well as the party programs. The General Hygiene Law of 1930 and the Physical Education Law of 1938 are proof of this (Alemdaroğlu, 2008). Since the couples to marry are considered as future parents candidates, the conditions for the realization of the marriage contract were determined in line with the view that 'healthy children/generations will be born from healthy parents'.

The necessity of the law is seen in the article written by Zeki Nasir in Ülkü, one of the publications of the period, and in the concerns of the period thinkers about the creation of healthy generations. It is seen that parents who will give birth and raise future generations have the necessary qualifications in terms of health and that marriage is considered as an issue that has social dimensions beyond being an individual contract. It is also noteworthy that protecting health is presented as a civic duty. For example, it is stated as "The sanitary standard of a nation, being strong and robust, naturally reproducing, advancing the body and soul, getting rid of epidemic diseases and thus having a long life." It was emphasized that "the health of the individual constitutes the health of the family, the health of the family, the health of the village, town and city, all of which constitute the health standard of a nation" (Nasir, 1933). Compulsory assignment of physical education and sports activities to citizens within the framework of the law was put into practice with the law numbered 3530 of 1938.

With the first article of the Physical Education Law No. 3530, 1938, it was announced that games, gymnastics and sports activities would be managed from a single center in order to educate citizens in accordance with the values of the nation state and to ensure the development of the revolution: "A General Directorate of Physical Education, which is affiliated with the Office of the Prime Minister and has a legal personality, has been established in order to direct and manage the games, gymnastics and sports activities that ensure the development of the physical and moral abilities of citizens according to national and revolutionary purposes" (Physical Education Law, 1938).

The General Directorate was established to organize games, gymnastics and sports activities that would ensure the development of the physical and moral abilities of the citizens in accordance with national and "revolutionary" purposes under the total control of the state. The third article of the law obliged young people to participate in sports clubs and physical education programs in their spare time. Physical education obligation was seen as a national obligation like military service. While the law was being discussed in the Turkish Grand National Assembly, Minister of Internal Affairs Şükrü Kaya saw physical education as the main pillar of national education. The law aimed to strengthen and beautify the body and to prepare the youth for the struggle for life (Y1ld1z, 2001).

In the book 'From National Chief to Turkish Youth' (Anonymous, 1942): “... the true athlete 
is a virtuous person who develops his/her physical ability to become a better citizen, better soldier, better parent and knows how to use sports as a tool. A force not put at the service of a civilized and moral ideal does not matter. We will do sports to be healthier, stronger, more resistant to all kinds of difficulties, to know and love each other. We will love sports as a way of working, which has national duties in its aim. Sport will be a school of good habits as well as a discipline for us" İsmet İnönü's (National Chief) words clearly revealed what was expected of sports and the social Darwinist perspective on sports in the early republican period.

\section{Conclusion}

The body, which has always been the subject of thought, research and understanding, is the place of existence of human as a human in social life. Human history is, in a way, the history of social orders, political powers, ideologies and religions' interventions in the body. All these power centers have sought and worked to ultimately establish control over individual bodies (Okumuş, 2009). Practices towards the productive capacity, welfare and health of the population constitute the backbone of modern politics. Therefore, it is seen that the state intervenes more in the social sphere and in the daily life of individuals in the formation process of the modern state. On the one hand, the modern state tries to increase the productive capacity of the individuals who make up the society by providing health and welfare services, and on the other hand, by giving weight to the social and moral control of the population, it tries to create this capacity (Özbek, 2013). With this capacity, it was aimed to come to the fore in the competition race in the capitalist world by demonstrating talent and power. The belief that strong states could only be possible with strong individuals with a common nation-consciousness led to the spread of eugenic policies and physical education sports practices. After the First World War, this issue became the priority of the Turkish state in its policies as in all European states. Especially after the establishment of the republic, the qualified manpower needed in every field tended to improve public health and increase production capacity. The founding staff aimed to achieve the targeted development by realizing the use of gymnastics/sports as pedagogical and political instruments (Arnaud, 2003) for the young state, in order to create the "national identity" of which the German Jahn and Czech Tyrs formed the first examples. Considering the multi-dimensional practices carried out in intensive work, the conditions of keeping health, marriage and population records, and marriage contract with the sanitation law were arranged with the rational management approach towards the national productivity target. A total recovery and development goal were aimed with the realization of 'healthy' marriages, thus healthy generations from healthy parents, and regular and disciplined sports activities with the understanding of "robust masses instead of athletic individuals". At this point, physical education and sports were handled as a tool, handled with the understanding of raising robust hundreds of thousands, and designed as a task, they were seen as the most economical way to defend the country, increase work efficiency, and restore and beautify the race.

\section{References}

Akin, Y. (2014). Robust ferocious sons: Physical education and sports in the early republic. 
İstanbul: İletişim Publications.

Alemdaroğlu, A. (2008). Eugenics thought. In T. Bora \& M. Gültekingil (Eds.), Political Thought in Modern Turkey 4: Nationalism (pp. 414-426). İstanbul: İletişim Publications.

Anonymous. (1942). From the National Chef to the Turkish Youth. Ankara: Maarif Printing Press.

Anonymous. (1934). On the revolution stand: Ismet Pasha's lesson on the revolution platform. Ülkü, 3(14), 81-87.

Anonymous. (1934). Stars and sport: Elizabeth Allen. Sport Postast, 16, 11.

Arnaud, P. (2003). Sport a means of national representation. In P. Arnaud \& J. Riordan (Eds.), Sport and international politics: The impact of fascism and communism on sport (pp. 3-13). London: Taylor \& Francis.

Arpac1, M. (2015). Body and population policies in the modernizing Turkey: Sanitation, education, eugenics (Unpublished Doctoral dissertation, Mimar Sinan University, İstanbul).

ATAM. (2006). The Speeches and Statements of Atatürk III. Atatürk High Institution of Culture, Language and History Atatürk Research Center. Retrieved from http://atam.gov.tr/ wp-content/uploads/S\%C3\%96YLEV-ORJ\%C4\%B0NAL.pdf

Balc1, A. (2006). Social sciences research: Methods, techniques and principles. Ankara: Pegem Publications.

Balcioğlu, M. (1999). From Ottoman Youth Associations to Revolution Youth Associations. ATAM, 15(43), 139-162.

Beşikçi, M. (2009). Militarism, Total War and Youth Mobilization: Paramilitary Associations in the Ottoman Empire in World War I. New Approaches to History and Society, 8, 49-92.

Bora, A. (2012). Sports and women as a national duty. Hacettepe Journal of Sport Sciences, 23(4), 220-226.

C.H.P. Program. (1935). Ankara: Ulus Printing House.

Cora, Y. T. (2013). Military-Citizens and hero men: Establishing ideal masculinity through physicaal education during the Balkan Wars and World War I. In N. Y. Sünbüloğlu (Ed.), Male Nation Soldier Nation: Militarism, Nationalism, Men in Turkey (pp. 45-74). İstanbul: İletişim Publications.

Demirci, A. (2014). Literature Review. Eds. Yılmaz Ar1, İlhan Kaya. Geography Research Methods (pp. 73-108). Balıkesir: Geographers Association Publications.

Foucault, M. (2004). Nietzsche, Genealogy, History. Philosophy Stage (pp. 230-253). İstanbul: Ayrintı Publications.

Foucault, M. (2011). About the archaeology of sciences: Response to the epistemology environment. Philosophy Stage (pp. 139-178). İstanbul: Ayrıntı Publications. 
Holt, R., \& Vigarello, G. (2011). Processed body. The history of body II (pp. 249-297). İstanbul: Yap1 Kredi Publications.

Kavasoğlu, İ., \& Y1ldıran, İ. (2016). Modern women's readings on female athletes in the early republican period. In C. Koca (Ed.), Gender aspects of sports (pp. 94-113). Ankara: Spor Publications.

Kerim, F. (1934). The nature of the eugenique issue in national population politics. Ülkü, 3(15), 206-212.

Keser, İ. K. (n.d.). Scientific research methods. Retrieved from http://kisi.deu.edu.tr//istem. koymen/BAY\%20sunum\%202.pdf

Koca, E., \& Koç, F. (2010). The effects of beauty contests on the formation of fashion awareness in Turkey. Retrieved from http://www.acarindex.com/dosyalar/makale/acarindex1423866466.pdf

Mazower, M. (2010). The dark continent: Europe's twentieth century. İstanbul: Yap1 Kredi Yayınları.

Mosse, G. L. (1975). The nationalization of the masses. New York: Howard Fetting.

Nabi, Y. (1939). Turkey on population issue. Ülkü, 19(79), 33-39.

Nasır, Z. (1933). Public health. Ülkü, 1(1), 73-75.

Okumuş, E. (2009). Sociology of body intervention. Journal of Oriental Studies, 2, 1-15.

Özbek, N. (2013). Social state in Ottomans. İstanbul: İletişim Publications.

Öztürkmen, A. (2002). Mehmet Fetgeri Şuenu and Physical Education in Women. Society and Science, 37(219), 4-9. https://doi.org/10.1111/j.2150-1092.2002.tb00371.x

Physical Education Law. (1938). Retrieved from https://www.tbmm.gov.tr/tutanaklar/KAN UNLAR_KARARLAR/kanuntbmmc018/kanuntbmmc018/kanuntbmmc01803530.pdf

Porter, D. (2005). Health, civilization and the state. Routledge. https://doi.org/10.4324/ 9780203980576

Şişman, N. (2006). From relic to property: woman, body, politics. İstanbul: İz Publications.

Steinitzer, H. (1912). Sport and kultur. Berlin: Verlag d. Dt. Alpenzeitung.

Tanar, M. (2011). Social Darwinism debates in Western Europe and its effects on the Ottoman world of thought (Unpublished Master's Thesis, Istanbul University Institute of Social Sciences, Department of International Relations).

Taşkesenlioğlu, M. Y. (2009). Establishment of the scouting organization in Turkey. Journal of Republic History Studies, 5(10), 103-116.

Toprak, Z. (1979). Paramilitary youth organizations of the Committee of Union and Progress. B.U. Journal of Humanities, VII, 95-113. 


\section{Macrothink}

Tuncay, M. (1999). Establishing a single party administration in the Republic of Turkey. İstanbul: Tarih Vakfi Yurt Publications.

Türkmen, M. (2012). Physical education and sports as a means of political socialization; worker sports and its effects in Turkey (1923-1938) (Unpublished Doctoral Thesis, Gazi University, Ankara).

Ünder, H. (2001). Goltz, nation and spartan elements in kemalism. History and Society, $35(206), 45-54$.

Webb, L., Quennerstedt, M., \& Öhman, M. (2008). Healthy bodies: Construction of the body and health in physical education. Sport, Education and Society, 13(4), 353-372. https://doi.org/10.1080/13573320802444960

Yamak, S. (2012). Raising military offspring: Physical education, military training and paramilitary youth organizations during the Second Constitutional Monarchy. İstanbul: İletişim Publications.

Yıldız, A. (2001). Happy to say that I am a Turk. İstanbul: İletişim Publications.

Yücel, S., \& Taşar, M. M. (2016). Social Darwinism: Its emergence, development and its effect on the Early Republic. Kutadgubilig Philosophy Science Research, 29, 309-340.

Yumul, A. (2012). Registering otherness into bodies. In K. Çayır, M. A. Ceyhan (Eds.), Discrimination: Multidimensional Approaches (pp. 89-96). İstanbul: İstanbul Bilgi University Publications.

\section{Notes}

Note 1. The highlights are mine.

Note 2. The influence of Goltz on the founding staff of the republic was not only realized through the education system or students of the Military War and the Military Academy, which he reformed, but also M. Kemal and İnönü examined Goltz's thoughts. When M. Kemal was a captain in Thessaloniki in 1909, he planned a maneuver that Goltz would follow and liked after watching, and he became Goltz's number one interlocutor as the person who planned the maneuver. İsmet İnönü also studied German with his friend Ali Fuat (Erden) by translating Goltz's Nation Müsellaha into Turkish (Ünder, 2001).

Note 3. The 1930 year announcement regarding the beauty contest organized by Cumhuriyet newspaper is as follows: "As one of the issues that emerged all over the world after the world war, we thought that the revolutionary Turkey should not be left behind from other countries and could not be left outside of the beauty contests held in every country ... Turkish women had risen to be people who were no different from free women in the free countries of the world. It would not be right not to take advantage of an opportunity to show this important truth and say it out loud” (Koca \& Koç, 2010). 


\section{Copyright Disclaimer}

Copyright for this article is retained by the author(s), with first publication rights granted to the journal.

This is an open-access article distributed under the terms and conditions of the Creative Commons Attribution license (http://creativecommons.org/licenses/by/3.0/). 